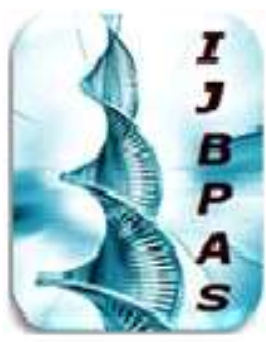

International Journal of Biology, Pharmacy and Allied Seiences (IJBPAS) 'A B ridge Botusen Laboratory and Qender'

www.jibpas.com

\title{
APPROPRIATE PERSONAL PROTECTIVE EQUIPMENT TO BE FOLLOWED IN COVID-19 PANDEMIC- A REVIEW
}

\section{CHITHRALEKHA $B^{1}$, GHEENA $S^{2}$ AND MADHULAXMI $\mathrm{M}^{3^{*}}$}

1: Saveetha Dental College and Hospitals, Saveetha University of Medical And Technical Science (SIMATS), Saveetha University, Chennai-600077, India

2: Reader, Department of Oral Pathology, Saveetha Dental College and Hospitals, Saveetha University of Medical And Technical Science (SIMATS), Saveetha University.Chennai600077 India

3: Professor, Department of Oral and Maxillofacial Surgery, Saveetha Dental College and Hospitals, Saveetha University of Medical And Technical Science (SIMATS), Saveetha University. 162, PH Road, Chennai-600077, Tamil Nadu, India

*Corresponding Author: E Mail: Dr. Madhulaxmi M: madhulaxmi.sdc@saveetha.com; Tel: $+917373814000$

Received 19 ${ }^{\text {th }}$ March 2021; Revised 20 ${ }^{\text {th }}$ April. 2021; Accepted 19 ${ }^{\text {th }}$ May 2021; Available online $1^{\text {st }}$ Aug. 2021 https://doi.org/10.31032/IJBPAS/2021/10.8.1004

\section{ABSTRACT}

The very recent outbreak of the coronavirus has propelled to a pandemic of such magnitude that we as humans have never experienced before. The first known case was reported by the 31st of December 2019 and from then onwards the virus has wreaked havoc in almost every nook and corner of the world, with the developing and the third world countries having to put up with the brunt of the pandemic. In this review the authors have tried to analyse and understand the effectiveness of the Personal Protective Equipments (PPE) being widely used by healthcare professionals all over the world with special emphasis on those being used by healthcare professionals in India. The review was done by collecting the data from various prominent medical journals and related websites like Pubmed, Research Gate, Google Scholar etc. Quality 
Assessment was done for the collected articles and was reviewed. It was found from the review that the existing Personal Protective Equipments being used by the vast majority of healthcare professionals are not completely effective in the battle against the Covid-19 pandemic. With the majority of the population in India experiencing humid climate, it is extremely overbearing for the frontline medical professionals to provide necessary care to the needy whilst wearing PPE's. This difficulty often leads to reducing the active usage time of the PPE kits. Hence more production of the same is required, sadly for which sufficient funds are not available in both the public and private sectors. Hence considering the above factors which require immediate attention, the government must take sufficient steps to ramp up the production of PPE kits to meet the rising demands of the same in the healthcare sector as the number of positive cases are rising almost exponentially.

\section{Keywords: PPE; CoVID-19; Health care workers; Infection Control}

\section{INTRODUCTION}

The Novel Coronavirus, Covid-19 (SARSCoV-2) [1, 2] has recently created a worldwide pandemic and since then the death rate has been increasing exponentially. It has been declared as a global emergency [3]. From the early 1900s humans have started discovering various types of viruses and three to four species of viruses are being discovered every year [4]. Viruses are known to be responsible for causing different diseases ranging from mild fevers to deadliest cancers [5-9]. It has been reported as the third documented pour-out of animal coronavirus to humans in the last two decades that has resulted in the current pandemic. Various researchers are applying metabolomics in studying the genetic variations of the virus but the novelty of the virus and the increasing spread is leaving the clinicians in a very stressful situation [10, 11].

The first case of infection was reported from the Hubei Province in the city of Wuhan in mainland China [12-16]. The outbreak was associated with the seafood and animal meat market in Hubei and investigations are ongoing to determine the source of the infection. The whole group of Coronavirus gained global attention back in 2003 when it caused the SARS (Severe Acute Respiratory Syndrome) epidemic in China and in 2012 when it caused the MERS (Middle East Respiratory Syndrome) epidemic in the middleeastern nations such as Bahrain, Lebanon Iran, Jordan, Kuwait, Oman, Qatar, Saudi Arabia, United Arab 
Emirates (UAE) and Yemen [17-21]. Out of all three strains of the Coronavirus, the SARS CoV and the MERS CoV have been found to be the most deadly [22-24].

With India still being a developing nation and the vast majority of its population being in the poor to average group, many people have found it hard to sustain their and their loved ones lives due to the lockdown imposed strictly throughout the country in order to battle the Covid-19 pandemic. The imposed lockdown has led to several bouts of unemployment and pay cuts of almost all the employees in both private and public sectors. We have also seen the mass exodus of migrant labourers from several regions of the nation towards their home states as they were left with no jobs and dwindling financial supplies [25, 26]. The current lockdown has given yet another blow to the Indian economy which was still reeling from the after effects of both demonetisation and the implementation of the Goods and Services Tax (GST). It is quite shameful that a government which has set its sight on becoming a five trillion dollar economy by 2024 is now facing backlash from all corners as several of the poor have already succumbed to starvation without being affected by the virus and many still on the brink of death.
We should also take note of the fact that the virus has spread vastly in several slum areas thereby making the already hard job of the healthcare workers more difficult. As of $22^{\text {nd }}$ May 2020, which was during the period of the review being conducted, the Ministry of Health and Family Welfare, Government of India have confirmed a total of 118447 positive cases, 48534 recoveries and 3583 deaths in the country. So far $22^{\text {nd }}$ May has seen the biggest single day spike in the number of infections when 6088 new cases were reported [27]. One of the main disadvantages that our healthcare workers are faced with is the shortage of PPE kits and low quality of the available PPE kits.

The fatality rate of Covid-19 in India when compared to other nations is less with it being $3.09 \%$ while the global fatality rate remains at $6.63 \%$ as of $20^{\text {th }}$ May 2020 [28]. As the tendency of people to get back to normal life is on the rise due to several socioeconomic factors, the greatest danger being faced by the healthcare workers is the possibility of a community spread. Hence we can say that frontline healthcare workers are at the most risk of contracting the virus. This possibility highlights the importance regarding availability and quality of PPE kits being issued to medical and security personnel. 


\section{MATERIALS AND METHODS}

In this review we have collected ten articles as primary articles and we have assessed the quality of these articles by the quality assessment tool given by Health Evidences. In this around ten criterias were included as follows:

1) Initially it was seen if the authors had a clearly focused population.

2) The inclusion criterias were analysed.

3) The search strategy used was a comprehensive strategy or not.

4) If the search strategy covered an adequate number of years.

5) Whether the author described the level of evidence in the primary studies included in the review.

6) If the review has assessed the methodological quality of the primary studies indicating the research designs, study sample, participation rate, source of bias, data collection, followup, data analysis etc.

7) Whether the author has analysed the results of the review were transparent or not.

8) Whether it was assessed as if it was appropriate to combine the findings of the results across various studies.

9) Whether there were appropriate methods adapted for combining or comparing the results across the studies.

10) And finally checked whether the data supported the authors interpretation.

Through this we have found that almost seven articles were strong in Quality Assessment and three of them were moderate.

\section{DISCUSSION}

From the review we have found that in order to prevent the spread of Covid-19 to the healthcare professionals extensive and effective usage of gloves, face masks, air purifying respirators, goggles, face shields, respirators and gowns should be done. Another major crisis that we have come across in the review was the shortage of these essential equipment which leave the healthcare workers directly in the path of the virus as they are then forced to attend to the affected patients without any of the protective wear.

The major reason for the use of these PPE kits are due to the fact that the virus can be transmitted through aerosols and it is more prone to happen so when giving supportive care. The healthcare workers must therefore be encouraged to use PPE kits extensively and effectively when interacting with likely cases of Covid-19. The medical personnel can also utilise facilities such as telephone, 
mobile apps etc to provide advisory or elective treatments to patients without severe illnesses.

According to the World Health Organisation the Personal Protective Equipment includes gloves, medical/ surgical face masks, goggles, face shields, gowns as well as items for specific procedures, filtering facepiece respirators i.e, N95 or FFP2 or FFP3 standard or equivalent as respirators and aprons.

Airborne transmission may occur during aerosol generating procedures and support treatments like tracheal intubation, non-invasive ventilation, tracheotomy, cardiopulmonary resuscitation, manual ventilation before intubation, bronchoscopy is being done [29-31].

Therefore some of the airborne precautions that we can suggest for these kind of procedures are:

- Maintaining physical distance (minimum one metre from individual)

- Maintaining hand hygiene frequently with an alcohol based hand rub.

- Avoiding touching eyes, nose and mouth frequently.

- Practising respiratory hygiene by coughing or sneezing into a bent elbow or tissue and then immediately disposing the tissues.
- Wearing a medical mask if you have respiratory symptoms and performing hand hygiene while and after disposing of the mask.

- Routine cleaning and disinfection of environmental and frequently touched surfaces.

- In health care settings, the main infection prevention and control (IPC) strategies to prevent or limit the CoVID- 19 transmission includes:[32]

Ensuring large, early recognition and source control. Applying standard precautions [33] for all patients and diligent hand hygiene.

Implementing empirical additional precautions (droplet and contact and wherever applicable for aerosol generating procedures and support treatments, airborne precautions) for suspected and confirmed cases of CoVID -19.

Implementing administrative controls.

Using environmental and engineering controls [34].

Why the personal protective equipment is so important during the pandemic is because during SARS we saw that $20 \%$ of the infection happened to the total population was to health care workers and this was because of the failure to properly use PPE $[35,36]$. During SARS itself it has been 
found that the personal protective equipment can only be worn usually for a shorter period of time and viruses like SARSCoV could survive in surfaces for hours and that the infection can spread from surface to hand by hand to hand contact[37-39]; and many studies have suggested that a double glove removal technique, where the outer glove is removed first and with the second glove, googles, apron, and other equipments are removed and then the second glove is finally removed [40, 41]. And few other studies have shown that using gloves has caused a belief that gloves make hand hygiene unnecessary which is completely wrong [42, 43].
Still many studies have reported that the intact role the air borne particles play in the spread of CoVID-19 pandemic remains unclear. Also few studies have concluded that it is arguable that personal protective equipment should be directed towards normal wards along with the ones that are with patients who are infected and in operation theatres [44].

Tao chan et al concluded that other than the commonly known respiratory distress the CoVID-19 is also responsible for systemic inflammation leading to multiorgan dysfunction in patients at high risk [45].

The following Table 1 represents the quality assessment done for the selected articles.

\begin{tabular}{|c|c|c|c|}
\hline S. No. & AUTHOR & YEAR & QUALITY ASSESSMENT \\
\hline $\mathbf{1}$ & Paul Coulthard & $\mathbf{2 0 2 0}$ & Strong \\
\hline $\mathbf{2}$ & JBT Herron & $\mathbf{2 0 2 0}$ & Moderate \\
\hline 3 & T.M Cook & $\mathbf{2 0 2 0}$ & Strong \\
\hline 4 & Peter M. Odor & $\mathbf{2 0 2 0}$ & Strong \\
\hline $\mathbf{5}$ & Joseph D Forrester & $\mathbf{2 0 2 0}$ & Moderate \\
\hline $\mathbf{6}$ & Edward Livingston & $\mathbf{2 0 2 0}$ & Strong \\
\hline $\mathbf{8}$ & J.Brown & $\mathbf{2 0 2 0}$ & Strong \\
\hline 9 & Shannon L.Lockhart & $\mathbf{2 0 2 0}$ & Moderate \\
\hline 10 & Lisa Casanova & $\mathbf{2 0 2 0}$ & Strong \\
\hline
\end{tabular}

\section{CONCLUSION}

As like the general public the lives of the health care workers are also of utmost importance. Using the most appropriate and effective personal protective equipment is the only way to save lives that has the potential to save hundreds and thousands of the general population.
It's a sad truth that even though we had two experiences in the past during SARS and MERS, still the medical sector has not advanced efficiently to be able to overcome a catastrophe of such magnitude. It clearly indicates that the health sector all over the world would need serious interventions in their way of handling a pandemic and the 
way they have to prepare for enduring another havoc at any point of time in the near future.

\section{REFERENCES}

[1] Gorbalenya AE, Baker SC, Baric RS, de Groot RJ. The species severe acute respiratory syndrome related coronavirus: classifying 2019-nCoV and naming it SARS-CoV-2. Nat Microbiol 5: 536-544. 2020;

[2] Saxena SK. Coronavirus Disease 2019 (COVID-19): Epidemiology, Pathogenesis, Diagnosis, and Therapeutics. Springer Nature; 2020. $213 \mathrm{p}$.

[3] Sohrabi C, Alsafi Z, O’Neill N, Khan M, Kerwan A, Al-Jabir A, et al. World Health Organization declares global emergency: A review of the 2019 novel coronavirus (COVID-19). Int J Surg. 2020 Apr; 76: 71-6.

[4] Woolhouse M, Scott F, Hudson Z, Howey R, Chase-Topping M. Human viruses: discovery and emergence. Philos Trans R Soc Lond B Biol Sci. 2012 Oct 19; 367(1604): 2864-71.

[5] Jayaraj G, Sherlin HJ, Ramani P, Premkumar P, Anuja N. Cytomegalovirus and Mucoepidermoid carcinoma: A possible causal relationship? A pilot study. J
Oral Maxillofac Pathol. 2015 Sep; 19(3): 319-24.

[6] Jayaraj G, Ramani P, Sherlin HJ, Premkumar P, Anuja N. Interobserver agreement in grading oral epithelial dysplasia--a systematic review. Journal of Oral and Maxillofacial Surgery, Medicine, and Pathology. 2015; 27(1): 112-6.

[7] Swathy S, Gheena S, Varsha SL. Prevalence of pulp stones in patients with history of cardiac diseases. Research Journal of Pharmacy and Technology. 2015; 8(12): 1625-8.

[8] Kumar A, Sherlin HJ, Ramani P, Natesan A, Premkumar P, Others. Expression of CD 68, CD 45 and human leukocyte antigen-DR in central and peripheral giant cell granuloma, giant cell tumor of long bones, and tuberculous granuloma: An immunohistochemical study. Indian J Dent Res. 2015;26(3):295.

[9] Gheena S, Ezhilarasan D. Syringic acid triggers reactive oxygen speciesmediated cytotoxicity in HepG2 cells. Hum Exp Toxicol. 2019 Jun 1; 38(6): 694-702.

[10] Sridharan G, Ramani P, Patankar S. Serum metabolomics in oral leukoplakia and oral squamous cell 
carcinoma. J Cancer Res Ther. 2017 Jul; 13(3): 556-61.

[11] Sridharan G, Ramani P, Patankar S, Vijayaraghavan R. Evaluation of salivary metabolomics in oral leukoplakia and oral squamous cell carcinoma. J Oral Pathol Med. 2019 Apr; 48(4): 299-306.

[12] Zhou P, Yang XL, Wang XG, Hu B, Zhang L, Zhang W. Discovery of a novel coronavirus associated with the recent pneumonia outbreak in humans and its potential bat origin. BioRxiv [Internet]. 2020; Available from:

https://www.biorxiv.org/content/10. 1101/2020.01.22.914952v2.abstract

[13] Zhang G, Zhang J, Wang B, Zhu X, Wang Q, Qiu S. Analysis of clinical characteristics and laboratory findings of 95 cases of 2019 novel coronavirus pneumonia in Wuhan, China: a retrospective analysis [Internet]. Available from: http://dx.doi.org/10.21203/rs.3.rs$17712 / \mathrm{v} 1$

[14] Viveka TS, Shyamsundar V, Krishnamurthy A, Ramani P, Ramshankar V. p53 Expression Helps Identify High Risk Oral Tongue Premalignant Lesions and
Correlates with Patterns of Invasive Tumour Front and Tumour Depth in Oral Tongue Squamous Cell Carcinoma Cases [Internet]. Vol. 17, Asian Pacific Journal of Cancer Prevention. 2016. p. 189-95. Available from: http://dx.doi.org/10.7314/apjcp.2016 .17 .1 .189

[15] Jangid K, Alexander AJ, Jayakumar ND, Varghese S, Ramani P. Ankyloglossia with cleft lip: A rare case report. $\mathrm{J}$ Indian $\mathrm{Soc}$ Periodontol. 2015 Nov;19(6):690-3.

[16] Hannah R, Ramani P, Sherlin HJ, Ranjith G, Ramasubramanian A, Jayaraj G, et al. Awareness about the use, ethics and scope of dental photography among undergraduate dental students dentist behind the lens. Research Journal of Pharmacy and Technology. 2018; 11(3): 10126.

[17] Tang Q, Song Y, Shi M, Cheng Y, Zhang W, Xia X-Q. Inferring the hosts of coronavirus using dual statistical models based on nucleotide composition. Sci Rep. 2015 Nov 26; 5: 17155.

[18] Song Z, Xu Y, Bao L, Zhang L, Yu $\mathrm{P}, \mathrm{Qu} \mathrm{Y}$, et al. From SARS to 
MERS, Thrusting Coronaviruses into the Spotlight. Viruses

[Internet]. 2019 Jan 14; 11(1).

Available from:

http://dx.doi.org/10.3390/v1101005

9

[19] Thangaraj SV, Shyamsundar V, Krishnamurthy A, Ramani P, Ganesan K, Muthuswami M, et al. Molecular Portrait of Oral Tongue Squamous Cell Carcinoma Shown by Integrative Meta-Analysis of Expression Profiles with Validations. PLoS One. 2016 Jun 9; 11(6): e0156582.

[20] Gupta V, Ramani P. Histologic and immunohistochemical evaluation of mirror image biopsies in oral squamous cell carcinoma [Internet]. Vol. 6, Journal of Oral Biology and Craniofacial Research. 2016. p. 194-7. Available from: http://dx.doi.org/10.1016/j.jobcr.201 6.06 .002

[21] Jayaraj G, Sherlin HJ, Ramani P, Premkumar P, Natesan A. Stromal myofibroblasts in oral squamous cell carcinoma and potentially malignant disorders. Indian $\mathrm{J}$ Cancer. 2015 Jan; 52(1): 87-92.

[22] Cui J, Li F, Shi Z-L. Origin and evolution

of

pathogenic coronaviruses. Nat Rev Microbiol. 2019 Mar; 17(3): 181-92.

[23] Sivaramakrishnan SM, Ramani P. Study on the Prevalence of Eruption Status of Third Molars in South Indian Population. Early Pregnancy. $2015 ; 7(4): 1$.

[24] Shree KH, Ramani P, Sherlin H, Sukumaran G, Jeyaraj G, Don KR, et al. Saliva as a diagnostic tool in oral squamous cell carcinoma--a systematic review with Meta analysis. Pathol Oncol Res. 2019; 25(2): 447-53.

[25] Lancet $T$, The Lancet. India under COVID-19 lockdown [Internet]. Vol. 395, The Lancet. 2020. p. 1315. Available from: http://dx.doi.org/10.1016/s01406736(20)30938-7

[26] Schueller E, Klein E, Tseng K, Kapoor G, Joshi J, Sriram A, et al. COVID-19 in India: Potential Impact of the Lockdown and Other Longer Term Policies. Retrieved from Washington DC: https://cddep org/publications/covid-19-indiapotentialimpact-of-the-lockdownand-other-longer-term-policies. 2020; 
[27] Bandyopadhyay R. Migrant Labour, Informal Economy, and Logistics Sector in a Covid-19 World. BORDERS OF AN EPIDEMIC. $: 31$.

[28] Roser M, Ritchie H, Ortiz-Ospina E, Hasell J. Coronavirus Pandemic (COVID-19). Our World in Data [Internet]. 2020; Available from: https://ourworldindata.org/coronavir us/country/denmark

[29] Conly J, Thakur R, Eremin S, Pessoa Silva C. Field evaluation (FE) of the World Health Organization (WHO) interim guidelines (IG) on infection prevention and control (IPC) of epidemic and pandemic-prone acute respiratory diseases (ARD) in health care [Internet]. Vol. 5, BMC Proceedings. 2011. Available from: http://dx.doi.org/10.1186/17536561-5-s6-p280

[30] Poole C, Nyquist A-C. Pathogens Spread via Respiratory Route [Internet]. Handbook of Pediatric Infection Prevention and Control. 2019. p. 1-30. Available from: http://dx.doi.org/10.1093/med/9780 190697174.003.0001

[31] Weston D, editor. Pandemic
Influenza. In: Infection Prevention and Control. West Sussex, England: John Wiley \& Sons Ltd; 2008. p. 241-56.

[32] Chan-Yeung M. Severe acute respiratory syndrome (SARS) and healthcare workers. Int $\mathrm{J}$ Occup Environ Health. 2004 Oct; 10(4): 421-7.

[33] Lau JTF, Fung KS, Wong TW, Kim JH, Wong E, Chung S, et al. SARS Transmission among Hospital Workers in Hong Kong [Internet]. Vol. 10, Emerging Infectious Diseases. 2004. p. 280-6. Available from:

http://dx.doi.org/10.3201/eid1002.0 30534

[34] Bean B, Moore BM, Sterner B, Peterson LR, Gerding DN, Balfour HH Jr. Survival of influenza viruses on environmental surfaces. J Infect Dis. 1982 Jul; 146(1): 47-51.

[35] Rabenau HF, Cinatl J, Morgenstern B, Bauer G, Preiser W, Doerr HW. Stability and inactivation of SARS coronavirus [Internet]. Vol. 194, Medical Microbiology and Immunology. 2005. p. 1-6. Available from: http://dx.doi.org/10.1007/s00430- 
004-0219-0

[36] Gwaltney JM. Hand-to-Hand Transmission of Rhinovirus Colds [Internet]. Vol. 88, Annals of Internal Medicine. 1978. p. 463. Available from:

http://dx.doi.org/10.7326/00034819-88-4-463

[37] Gwaltney JM Jr, Hendley JO. Transmission of experimental rhinovirus infection by contaminated surfaces. Am J Epidemiol. 1982 Nov; 116(5): 82833.

[38] Casanova L, Alfano-Sobsey E, Rutala WA, Weber DJ, Sobsey M. Virus transfer from personal protective equipment to healthcare employees' skin and clothing. Emerg Infect Dis. 2008 Aug; 14(8): 1291-3.

[39] Pittet D. Improving Adherence to Hand Hygiene Practice: A Multidisciplinary Approach [Internet]. Vol. 7, Emerging Infectious Diseases. 2001. p. 23440. Available from: http://dx.doi.org/10.3201/eid0702.0 10217

[40] Santarpia JL, Rivera DN, Herrera V, Jane Morwitzer $M$, Creager $H$,
Santarpia GW, et al. Transmission Potential of SARS-CoV-2 in Viral Shedding Observed at the University of Nebraska Medical Center [Internet]. Available from: http://dx.doi.org/10.1101/2020.03.2 3.20039446

[41] Marasinghe KM. Concerns around public health recommendations on face mask use among individuals who are not medically diagnosed with COVID-19 supported by a systematic review search for evidence [Internet]. Available from: http://dx.doi.org/10.21203/rs.3.rs$16701 / \mathrm{v} 3$

[42] Lockhart SL, Duggan LV, Wax RS, Saad S, Grocott HP. Personal protective equipment (PPE) for both anesthesiologists and other airway managers: principles and practice during the COVID-19 pandemic [Internet]. Canadian Journal of Anesthesia/Journal canadien d'anesthésie. 2020. Available from: http://dx.doi.org/10.1007/s12630020-01673-w

[43] Brown J, Pope C. Personal protective equipment and possible routes of airborne spread during the COVID -19 pandemic [Internet]. 
Anaesthesia. 2020. Available from: http://dx.doi.org/10.1111/anae.1509 7

[44] Cook TM. Personal protective equipment during the coronavirus disease (COVID) 2019 pandemic a narrative review [Internet]. Vol. 75, Anaesthesia. 2020. p. 920-7. Available from: http://dx.doi.org/10.1111/anae.1507 1

[45] Chen T, Wu D, Chen H, Yan W, Yang D, Chen G, et al. Clinical characteristics of 113 deceased patients with coronavirus disease 2019: retrospective study. BMJ. 2020 Mar 26; 368: m1091. 